Original Article

\title{
Explore the antiproliferative phytocompounds from ethanolic extracts of Citrus paradisi against liver cancer cell line by chemical analysis using TLC and FT-IR spectroscopy
}

\author{
Explorar os fitocompostos antiproliferativos de extratos etanólicos de Citrus \\ paradisi contra linhagem de células de câncer de fígado por análise química usando \\ espectroscopia de TLC e FT-IR
}

\author{
M. Sharif** (D, F. Ansaria (D), N. Ul Hassan ${ }^{\mathrm{b}}$ (D), K. Sultana ${ }^{\mathrm{b}}$ (D) and Q. Ali ${ }^{\mathrm{a}}$ (1) \\ aThe University of Lahore, Institute of Molecular Biology and Biotechnology, Lahore, Pakistan \\ 'The University of Lahore, Department of Pharmacy, Lahore, Pakistan
}

\begin{abstract}
The aim of the present study was to evaluate the in vitro antiproliferative activity of ethanolic extract of leaves and fruits Citrus paradisi plant on HepG-2 liver cell lines by MTT (3-(4,5-dimethyl-2-thiazolyl)-2,5-diphenyl-2Hterazolium bromide) assay and to isolate and characterize the antiproliferative compounds by TLC (Thin layer chromatography) and FT-IR (Fourier transforms Infrared) spectroscopy. Qualitative phytochemical screening tests were performed to detect phytochemicals compounds from the crude extracts. Antioxidant activity of the plant extracts were characterized by using DPPH (2,2-Diphenyl-1-picrylhydrazyl) free radical scavenging method. The results showed that antioxidant activity using DPPH were found to be increased in a concentration dependent manner and decreased cell viability and cell growth inhibition in a dose dependent manner. The findings from this study indicated that fruit extract exhibited good antiproliferation and antioxidant potential. The seven functional groups of phytocompounds such as carboxylic acid, amine salt, aromatic compounds, cyclic alkene, aldehyde, fluoro compounds and alkene were detected by FT-IR which indicated that fruit extracts of Citrus paradisi possessed vast potential as a medicinal drug especially in liver cancer treatment.
\end{abstract}

Keywords: Citrus paradisi, liver cancer cell line, ethanol, anti-proliferation, bioactive compounds, phytochemicals, antioxidant.

\begin{abstract}
Resumo
O objetivo do presente estudo foi avaliar a atividade antiproliferativa in vitro do extrato etanólico de folhas e frutos da planta Citrus paradisi em linhagens de células hepáticas HepG-2 por MTT (3- (4, 5-dimetil-2-tiazolil) -2, Ensaio de brometo de 5-difenil-2H-terazólio) e isolar e caracterizar os compostos antiproliferativos por espectroscopia de TLC (cromatografia de camada fina) e FT-IR (infravermelho com transformadas de Fourier). Testes qualitativos de triagem fitoquímica foram realizados para detectar compostos fitoquímicos nos extratos brutos. A atividade antioxidante dos extratos vegetais foi caracterizada pelo método de eliminação de radicais livres DPPH (2,2-difenil-1-picrilhidrazil). Os resultados mostraram que a atividade antioxidante usando DPPH aumentou de uma maneira dependente da concentração e diminuiu a viabilidade celular e a inibição do crescimento celular de uma maneira dependente da dose. Os resultados deste estudo indicaram que o extrato de fruta exibiu bom potencial antiproliferação e antioxidante. Os sete grupos funcionais de fitocompostos, como ácido carboxílico, sal de amina, compostos aromáticos, alceno cíclico, aldeído, compostos de flúor e alceno, foram detectados por FT-IR, o que indicou que extratos de frutas de Citrus paradisi possuíam vasto potencial como medicamento, especialmente no tratamento de câncer do fígado.
\end{abstract}

Palavras-chave: Citrus paradisi, linhagem de células de câncer de fígado, etanol, antiproliferação, compostos bioativos, fitoquímicos, antioxidantes.

\section{Introduction}

Citrus paradisi (Grapefruit) relates to the Citrus genus, a taxa of flowering plants in the family Rutaceae. Other members of the genus consist of oranges, lemons, limes, citrons, pomelos (pummelo, pommelo) and mandarins (tangerines). Citrus fruits are a distinctive berry with the internal parts divided into segments. The number of

*e-mail: musarratsharif388@gmail.com

Received: September 30, 2021 - Accepted: December 7, 2021 
natural species is not clear, as many of the named species are hybrids. The grapefruit is supposed to have arisen from the pomelo or shaddock (Citrus grandis) or as a hybrid between pomelo and sweet orange (Bailey and Dresser, 2004). Citrus is one of the most consumed fruits in the world and contain a high number of useful by-products which include essential oils. It is mostly consumed fresh or used as raw materials for juice and wine. The second largest world produced citrus species is Citrus paradisi, with an average of more than 60 million annual productions. The yield of grapefruit and oranges juice is about half of the fruit weight thereby generating a very high amount of waste annually. It has been used as a folk medicine in many countries as anti-bacterial, anti-fungal, anti- inflammatory, anti-microbial, anti-oxidant, anti-viral, astringent and preservative. It has also been used for cancer prevention, cellular regeneration, lowering of cholesterol, cleansing, detoxification, heart health maintenance, lupus nephritis, rheumatoid arthritis and weight loss (Okunowo et al., 2013; Danish et al., 2020).

Grapefruit is a very common variety of citrus fruit and an important source of bioactive compounds such as vitamins C, E, A, phenolic compounds (flavonoids, phenolic acids and coumarins) and terpenic substances, such as carotenoids and limonoids (Kelebek, 2010). An important component of $C$. paradisi is vitamin C. It is an essential micronutrient for humans, with pleiotropic functions related to its ability to donate electrons and a potent antioxidant and a cofactor for a family of biosynthetic and gene regulatory enzymes. Vitamin $C$ contributes to immune defense by supporting various cellular functions of both the innate and adaptive immune system (Traber and Stevens, 2011; Ashfaq et al., 2021). It supports epithelial barrier function against pathogens and promotes the oxidant scavenging activity of the skin, thereby potentially protecting against environmental oxidative stress. Vitamin C deficiency results in impaired immunity and higher susceptibility to infections. Furthermore, supplementation with vitamin C appears to be able to both prevent and treat respiratory and systemic infections. Prophylactic prevention of infection requires dietary vitamin $C$ intakes that provide at least adequate, if not saturating plasma levels (that is 100 to $200 \mathrm{mg} /$ day), which optimize cell and tissue levels (Carr and Maggini, 2017).

Hepatocellular carcinoma (HCC) is a primary liver cancer, reported as the leading cause of cancer-associated deaths due to poor prognosis. HCC is annually diagnosed in more than 6 million people and accounts for more than $80 \%$ of liver cancer cases. Currently, there is no clinically proven effective therapy for advanced liver cancer patients (El-Serag, 2011; Yang and Roberts, 2010; Siddique et al., 2021). Due to the large-scale development of acquired or intrinsic chemo-resistance, the majority of HCC patients do not respond to available chemotherapies. Thus, the development of effective and novel therapies is of utmost priority to combat such a devastating disease. Plants are known as important sources of new chemical entities suitable for anticancer drug discovery and development and many plant species are already being used to treat or prevent the development of cancer. Multiple researchers have identified different species of plants that have demonstrated anticancer properties with a lot of focus on those that have been used in herbal medicine in developing countries (Spangenberg et al., 2009; Khalil et al., 2020a, b).

\section{Materials and Methods}

\subsection{Collection and identification of plant materials}

Citrus paradisi plant i.e. leaves and fruits were collected from Okara, Pakistan and were identified by Dr. Zahoor Ahmad Sajid, Assistant Professor, Department of Botany, University of Punjab, Lahore, Pakistan. The plant specimen was deposited in the specially maintained garden, The University of Lahore, Lahore, Pakistan.

\subsection{Extraction procedure}

The plant materials (i.e. leaves and fruits) of Citrus paradisi were individually washed with distilled water to purge dust, dirt, shade dried at $25-30^{\circ} \mathrm{C}$ and crushed or pulverized into fine powder by grinding machine and then store in airtight container for extraction. The $2 \mathrm{~kg}$ each stored powdered plant materials of leaves and fruits were taken and dipped in ethanol at room temperature for seven days with vigorous shaking separately and then filtered through Whatman No 1. The filtrates were evaporated under reduced pressure by vacuum rotary evaporator at $35^{\circ} \mathrm{C}$ to obtain crude extracts and stored at $4^{\circ} \mathrm{C}$ for further use.

\subsection{Phytochemical analysis}

There are number of tests for the detection of phytochemicals in the plants part but from each context these tests were performed for the detection. Phytochemical analysis of all parts of $C$. paradisi was done by Molisch's test, Benedict's test, Fehling's test, Wagner's test, Hager's test, alkaline reagent test, lead acetate test, gelatin test, Braymer's test, Salkowski test and opened loop-closed loop response test (Morsy, 2014).

\subsubsection{Detection of carbohydrates}

\subsubsection{Molisch's test}

It was a sensitive chemical test for the presence of carbohydrates, based on the dehydration of the carbohydrate by hydrochloric acid to produce an aldehyde, which condensed with two molecules of phenols (alphanaphthol). $\alpha$-naphthol was called the Molisch reagent ( $\alpha$-naphthol dissolved in ethanol). The test reagent dehydrates pentose's to form furfural (op reaction) and dehydrates hexoses to form 5- hydroxymethyl furfural (bottom reaction). The furfurals further reacted with $\alpha$-naphthol present in the test reagent to produce a purple product. One $\mathrm{mL}$ of filtrate solution was treated with two drops of alcoholic $\alpha$-naphthol solution in a test tube. Two $\mathrm{mL}$ of concentrated sulfuric acid was added on the side of the test tube. Formation of the violet ring at the junction indicated the presence of carbohydrates. 


\subsubsection{Benedict's test}

One $\mathrm{mL}$ of filtrate solution was treated with Benedict's reagent and heated gently. Reddish precipitate indicated the presence of reducing sugars.

\subsubsection{Fehling's test}

One $\mathrm{mL}$ of filtrate solution was hydrolyzed with dilute hydrochloric acid neutralized with alkali and heated with Fehling's A and B solutions. Formation of reddish precipitates showed the presence of reducing sugars.

\subsubsection{Detection of alkaloids}

\subsubsection{Wagner's test}

It was an aqueous solution of iodine and potassium iodide, used for microchemical analysis of alkaloids. It was also called Wagner's solution. Wagner's test gives a reddish-brown precipitate that confirmed the presence of alkaloids. Another filtrate portion was treated with Wagner's reagent (iodine in potassium iodide). Formation of brown/reddish precipitates indicated the presence of alkaloids.

\subsubsection{Hager's test}

The last filtrate portion was treated with Hager's reagent (saturated picric acid solution). Formation of yellow colored precipitate indicated the presence of alkaloids.

\subsubsection{Detection of flavonoids}

\subsubsection{Alkaline reagent test}

Alkaline reagent test comprised of reducing sugars being heated in the presence of an alkali get converted to powerful reducing species known as enediols. Enediols reduced the cupric compounds $\left(\mathrm{Cu}^{2+}\right)$ present in the Benedict's reagent to cuprous compounds $\left(\mathrm{Cu}^{+}\right)$which get precipitated as insoluble red copper (I) oxide $\left(\mathrm{Cu}_{2} \mathrm{O}\right)$. Extract samples were treated with a few drops of sodium hydroxide solution. Formation of intense yellow color which became colorless on addition of dilute acid indicated the presence of flavonoids.

\subsubsection{Lead acetate test}

Extract samples were treated with few drops of lead acetate solution. Formation of yellow color precipitate indicated the presence of flavonoids.

\subsubsection{Detection of tannins}

\subsubsection{Gelatin test}

To the extracts, $1 \%$ gelatin solution containing sodium chloride was added. Formation of white precipitates indicated the presence of tannins.

\subsubsection{Braymer's test}

The ethanolic extracts of the plant parts were treated with $10 \%$ alcoholic $\mathrm{FeCl}_{3}$. The blue-black or green color showed the presence of tannins.

\subsubsection{Detection of steroids and triterpenoids}

\subsubsection{Salkowski test}

It was not specific for cholesterol but may be used for other sterols. It yielded a bluish red to purple color when cholesterol was treated with chloroform and concentrated sulphuric acid. The extract samples were dissolved in chloroform and equal volume of concentrated sulphuric acid was added. Bluish red, cherry red and purple color in chloroform layer indicated the presence of sterols while formation of reddish-brown color of the interface indicated the presence of triterpenoid nucleus.

\subsubsection{Detection of saponins}

\subsubsection{Froth test}

Froth's test involved a layer formed on the water surface in the presence of saponin. $10 \mathrm{~mL}$ distilled water was the reagent used in the said test. If the honey comb froth was greater than $2 \mathrm{~cm}$, height from the surface of the liquid persists after 10 minutes, the sample was considered positive for saponins. Crude dry powder of extract was vigorously shaken with $2 \mathrm{~mL}$ of distilled water and was allowed to stand for 10 minutes. If stable froth appeared, it indicated the presence of saponins.

\subsubsection{Blood hemolysis test}

$5 \mathrm{~mL}$ of the alcoholic extract was evaporated to dryness under vacuum and the residue was dissolved in $10 \mathrm{~mL}$ of normal saline. To $8 \mathrm{~mL}$ of this solution $2 \mathrm{~mL}$ of defibrinated blood in normal saline (1:40) were added and left for 24 hours. Blood hemolysis was noticed, indicated the presence of saponins.

\subsubsection{Detection of coumarins}

\subsubsection{Opened loop and closed loop response test}

In the test tube, 2 drops of $1 \%$ sodium hydroxide solution was added and heated in boiling water for 3 minutes to get a cleared solution. 4 drops of $2 \%$ hydrochloric acid was added to the solution. If the solution became cloudy it indicated the presence of coumarins and lactones.

\subsection{Antioxidant activity}

The antioxidant activity of Citrus paradisi plant extracts were evaluated by using the DPPH free radical scavenging assay described by Nithianantham et al., 2011. $50 \mu \mathrm{L}$ of Citrus paradisi extracts in concentrations from 1 to $5 \mathrm{mg} /$ $\mathrm{mL}$ and $5 \mathrm{~mL} 0.004 \%$ solution of DPPH was added in test tubes. The obtained mixture was vortexed, incubated for 30 minutes in room temperature in dark area and then took reading using spectrophotometer at $517 \mathrm{~nm}$. The blank was $80 \%$ methanol. Ascorbic acid was used as positive control. Test was performed in triplicate. DPPH scavenging effect was calculated by the following formula (Equation 1):

$$
\text { DPPH scavenging effect }(\%)=\{A 0-A \div A 0\} \times 100
$$


$\mathrm{A} 0$ is the absorbance of negative control $(0.004 \% \mathrm{DPPH}$ solution) and $\mathrm{A}$ is the absorbance of extract. The results were reported as IC50 values and ascorbic acid equivalents (mg/g) of Citrus paradisi.

\subsection{Anti-proliferative activity}

Standard MTT assay was used for evaluation of cell viability (Amjed et al., 2017). Cell lines were obtained from cell culture Center for Research in Molecular Medicine Laboratory (CRiMM), The University of Lahore, Lahore, Pakistan where cell culture experiments were performed. For testing, cells were washed by phosphate buffer saline (PBS), harvested by trypsinization and were plated in 96 well plates (one cells/well) and incubated under 5\% $\mathrm{CO}_{2}$ and $95 \%$ air at $37^{\circ} \mathrm{C}$ for 24 hours. The cells were treated with different concentrations of plants extracts. Dilution of stock solutions was made in culture medium yielding final extracts concentrations with a final DMSO (dimethyl sulfoxide) concentration of $0.1 \%$. This concentration of DMSO did not affect cell viability. Control cells were incubated in culture medium only. All concentrations of plants extracts were in triplicates on the same cell batch.

\subsubsection{MTT Assay}

Growth of tumoral cells quantitated by the ability of living cells to reduce the yellow dye MTT to a blue formazan product (Amjed et al., 2017). At the end of 72 hours incubation, the medium in each well was replaced by MTT solution (20 cell/well, $5 \mathrm{mg} / \mathrm{ml}$ in phosphatebuffered saline), the plates were incubated for 4 hours under $5 \% \mathrm{CO}_{2}$ and $95 \%$ air at $37^{\circ} \mathrm{C}$. MTT reagent was removed and the formazan crystals produced by viable cells were dissolved in $100 \mathrm{~mL}$ dimethyl sulfoxide (DMSO) and gently shaken. The absorbance was then determined by ELISA (Enzyme Linked Immunosorbent Assay) reader at $492 \mathrm{~nm}$. The effects of extracts were expressed by IC50 values (the drug concentration reducing the absorbance of treated cells by $50 \%$ with respect to untreated cells). The percentage growth inhibition was calculated using following formula (Equation 2),

$$
\% \text { cell inhibition }=100-\left[\left(A_{t}-A_{b}\right) /\left(A_{c}-A_{b}\right)\right] \times 100
$$

Where, $A_{t}=$ absorbance value of test compound, $A_{b}=$ Absorbance value of blank and $A_{c}=$ Absorbance value of control.

\subsection{Thin layer chromatography (TLC)}

Ethanolic extract of each plant sample was subjected to TLC studies. For the TLC analysis the dimensional ascending method was used (Gujjeti and Mamidala, 2013). $20 \times 20 \mathrm{~cm}$ TLC plate coated with silica gel 60 GF254 was cut with a scissor in $14 \times 3 \mathrm{~cm}$ shape. The plate was then marked with the pencil softly $1.5 \mathrm{~cm}$ far from the both bottom and top. Glass capillaries were used to spot the sample on the TLC plate on the pencil marked bottom line. Then it was placed in the fume hood to dry the plate and loaded the sample again until a dark spot is obtained. Then the solvents about $20 \mathrm{~mL}$ was taken in chamber. The plate was placed in the chamber lining on the top. After the run, plates were dried in the fume hood and then used to detect the spots. All the plates were dried and detected the spots with the help of UV light at $254 \mathrm{~nm}$ and $366 \mathrm{~nm}$ (Biradar and Rachetti, 2013). The movement of active compound was expressed by the retention factor (Rf). Rf values calculated for all the observed spots according to the following formula (Equation 3):

$R f=$ distance travelled by solute / distance travelled by solvent

\subsection{Column chromatography}

Forty grams silica gel was dissolved in ethanol solvent and loaded in cleaned, dry column that aligned in vertical portion. The column was tapped gently to level the surface of the silica gel and filled with solvent. One gram of extract was loaded and mobile phase was poured continuously to the top of the column by aid of a funnel. The bottom outlet of the column was opened. The fractions were collected in separate test tubes and numbered consecutively for further analysis on thin layer chromatography. TLC plate showing number of spots (compounds) for each fraction (Wahyuni et al., 2016).

\subsection{Fourier Transform Infrared Spectrometer (FTIR) analysis}

Fourier Transform Infrared Spectrometer is perhaps the most powerful tool for identifying the types of chemical bonds (functional groups) present in compounds. The wavelength of light absorbed is characteristic of the chemical bond as can be seen in the annotated spectrum. By interpreting the infrared absorption spectrum, the chemical bonds in a molecule can be determined. Dried powder of extracts of each part of Citrus paradisi plant materials were used for FTIR analysis. 10mg of the dried extract powder was encapsulated in $100 \mathrm{mg}$ of $\mathrm{KBr}$ pellet, in order to prepare translucent sample discs. The powered sample of each extract was loaded in FTIR spectroscope with a scan range from 400 to $4000 \mathrm{~cm}-1$ with a resolution of 4cm-1 (Ashokkumar and Ramaswamy, 2014).

\subsection{Statistical analysis}

Data obtained from different assays will be statistically analyzed via SPSS and graph pad software.

\section{Results and Discussion}

Hepatocellular carcinoma (HCC) is one of the most common malignancies, responsible for an estimated one million deaths annually (Fecht Junior and Befeler, 2004). Therefore, it becomes important to discover new agents which are effective on growth inhibition of HCC. Taking this into consideration, the present study was conducted on HepG-2 cell lines. HepG-2 is adherent, epithelial-like cells growing as monolayers and in small aggregates, has a model chromosome number of 55 . HepG-2 cell line was derived from the liver tissues. These HepG-2 cell lines have previously been used for evaluation of the cytotoxic potential of fruit extracts (Abu Bakar et al., 2015).

The phytochemical study revealed the presence of various phytocompounds in ethanolic Citrus paradisi 
plant extracts. There are four parts of $C$. paradisi plant were used for analysis of phytocompounds such as leaves and fruits. In the ethanolic fruit extract of $C$. paradisi, various phytocompounds like carbohydrates, alkaloids, flavonoids, terpenoids and coumarin were present. However, in ethanolic leaves extract, carbohydrates, alkaloids, terpenoids and coumarin were present. The results of preliminary phytochemical analysis are tabulated in Table 1. Preliminary phytochemical analysis of peel extract of $C$. paradisi revealed presence of flavonoids, sterols, triterpenoids, coumarins, glycosides, reducing sugars and carbohydrates, but alkaloids, tannins, saponins, anthraquinones and lignin were not detected, and might be present in trace undetectable amounts by qualitative methods. These principles have been known for many years to exhibit biological activity such as effects on the central nervous system, anti-bacterial, anti-tumor and anthehelmintic activities (Harborne, 1973). Compared with previous studies, Mathew et al. (2012) reported the presence of flavonoids, alkaloids, steroids, terpenoids, saponins, cardiac glycosides and reducing sugars. Generally, phytochemicals are known to confer certain health benefits such as anti-inflammatory, anti-microbial, anti-hypertensive and anti-diabetic effects (Oikeh et al., 2013, 2015).

Antioxidant potential of Citrus paradisi extracts was assessed by DPPH radical scavenging assay. From the analysis it was concluded that the scavenging effects of fruit extracts of Citrus paradisi were excellent with IC50 values $=38.885 \pm 0.38 \mu \mathrm{g} / \mathrm{mL}$ while leaves extracts exhibited poor antioxidant potential in comparison with positive control such as ascorbic acid with IC50=91.97 \pm 0.04 . The DPPH radical scavenging activity results are shown in Table 2 as comparable with known antioxidant ascorbic acid (Vitamin C).

In the free radical scavenging assays, DPPH possesses a distinctive absorbance at $517 \mathrm{~nm}$ which significantly decreases on exposure to radical scavengers by donating a hydrogen atom to become a stable diamagnetic molecule. The principle of the reduction of DPPH free radical is that the antioxidant reacts with the stable free radical DPPH and converts it to 1,1- diphenyl-2-picryl hydrazine. DPPH free radical has been widely used to test the free radical scavenging ability of Citrus paradisi and Naringin. The antioxidant present neutralizes the DPPH by the transfer of an electron or hydrogen atom. The reduction capacity of DPPH could be determined by color changes from purple to yellow by reading at $517 \mathrm{~nm}$. The ethanolic extract of Citrus paradisi and Naringin demonstrated H-donor activity. The DPPH radical scavenging activity of extracted material of Citrus paradisi and Naringin was detected and compared with standard ascorbic acid. The extract and Naringin tested against DPPH stable radical revealed that the radical scavenging activity of Citrus paradisi extract and Naringin possess good anti-oxidant capacity. The IC50 value of ethanolic extract of Citrus paradisi were found at the concentration of $382 \mu \mathrm{g} / \mathrm{mL}$ and Naringin exhibited $80 \mu \mathrm{g} / \mathrm{ml}$ concentrations while the standard ascorbic acid at $212 \mu \mathrm{g} / \mathrm{mL}$ (Roghini and Vijayalakshmi, 2018). The order of free radical scavenging activities of 4 citrus oils was distilled C. paradisi oil $>$ cold-pressed C. paradisi oil $>$ distilled $C$. grandis oil $>$ coldpressed $C$. grandis oil. Cold-pressed $C$. grandis oil exhibited the lowest activity in all antioxidative assays (Ou et al., 2015; Castro-Vazquez et al., 2016).

Crude ethanolic extract of leaves and fruits of Citrus paradisi plant were assayed against HepG-2 (liver cancer) cell line by using MTT Assay and results were expressed in terms of percentage viability and IC50. Different concentrations i.e. $25 \mu \mathrm{g} / \mathrm{mL}, 50 \mu \mathrm{g} / \mathrm{mL}, 100 \mu \mathrm{g} / \mathrm{mL}$, $300 \mu \mathrm{g} / \mathrm{mL}, 625 \mu \mathrm{g} / \mathrm{mL}, 1250 \mu \mathrm{g} / \mathrm{mL}$ of the plant extracts were tested for the anti-proliferative activity and all of these concentrations exhibited anti-proliferative activity, the fifty percentage of cell death occurred between 36 to $71 \mu \mathrm{g}$ of plant extract and highest cell death occurred at $1250 \mu$. The results of percentage viability of $C$. paradisi plant extracts are given in Table 3 and Figure 1 and 2.

Table 1. Qualitative phytochemical screening of Citrus paradisi ethanolic plant extracts.

\begin{tabular}{|c|c|c|c|c|}
\hline \multirow{2}{*}{ Active constituents } & \multirow{2}{*}{ Chemical test } & \multirow{2}{*}{ Positive results } & \multicolumn{2}{|c|}{ Plant extracts } \\
\hline & & & CPFRE & CPLE \\
\hline \multirow[t]{3}{*}{ Carbohydrates } & Molisch's test & Violet ring at the junction & + ve & + ve \\
\hline & Benedict's test & Reddish ppt & + ve & - ve \\
\hline & Fehling's test & Reddish ppt & - ve & - ve \\
\hline \multirow[t]{2}{*}{ Alkaloids } & Wagner's test & Brown/reddish ppt & + ve & - ve \\
\hline & Hager's test & Yellow ppt & + ve & + ve \\
\hline \multirow[t]{2}{*}{ Flavonoids } & Alkaline reagent test & Yellow color & + ve & - ve \\
\hline & Lead acetate test & Yellow color & + ve & - ve \\
\hline \multirow[t]{2}{*}{ Tannins } & Gelatin test & White ppt & - ve & - ve \\
\hline & Braymer's test & Blue-black or green color & - ve & - ve \\
\hline Terpenoides & Salkowski's test & Red, purple or reddish & + ve & + ve \\
\hline Coumarin & $\begin{array}{l}\text { Open loop closed loop } \\
\text { response test }\end{array}$ & Cloudy & + ve & + ve \\
\hline
\end{tabular}

CPFrE: Citrus paradisi fruit ethanol; CPLE: Citrus paradisi leave ethanol; +ve: presence; -ve: absence; ppt: precipitation. 
Table 2. Antioxidant activity by 2,2-Diphenyl-1-picrylhydrazyl (DPPH).

\begin{tabular}{|c|c|c|c|c|c|c|c|}
\hline Extracts & $\begin{array}{l}\text { Conc. } \\
(\mu \mathrm{g} / \mathrm{ml})\end{array}$ & $\begin{array}{c}\text { Absorbance } \\
\text { (reading 1) }\end{array}$ & $\begin{array}{l}\text { Absorbance } \\
\text { (reading 2) }\end{array}$ & $\begin{array}{c}\text { Absorbance } \\
\text { (reading 3) }\end{array}$ & Mean & $\%$ SCV & $\begin{array}{c}\text { IC50 }(\mu \mathrm{g} / \mathrm{ml}) \\
\pm \text { Standard } \\
\text { deviation }\end{array}$ \\
\hline \multirow[t]{5}{*}{ CPFrE } & 50 & 0.2046 & 0.2099 & 0.2071 & 0.207 & 49.952 & \multirow[t]{5}{*}{$38.885 \pm 0.38$} \\
\hline & 100 & 0.1641 & 0.1632 & 0.1616 & 0.163 & 60.636 & \\
\hline & 150 & 0.1213 & 0.1287 & 0.1265 & 0.126 & 69.686 & \\
\hline & 200 & 0.1077 & 0.1017 & 0.1026 & 0.104 & 74.879 & \\
\hline & 250 & 0.0747 & 0.0741 & 0.0737 & 0.074 & 82.085 & \\
\hline \multirow[t]{5}{*}{ CPLE } & 50 & 0.2501 & 0.2566 & 0.2548 & 0.254 & 38.688 & \multirow[t]{5}{*}{$114.985 \pm 0.46$} \\
\hline & 100 & 0.2427 & 0.2421 & 0.2489 & 0.245 & 40.926 & \\
\hline & 150 & 0.1417 & 0.1437 & 0.1457 & 0.144 & 65.290 & \\
\hline & 200 & 0.1388 & 0.1367 & 0.1399 & 0.138 & 66.554 & \\
\hline & 250 & 0.1331 & 0.1321 & 0.1311 & 0.132 & 68.092 & \\
\hline \multirow{5}{*}{$\begin{array}{l}\text { Ascorbic } \\
\text { acid }\end{array}$} & 50 & 0.172 & 0.169 & 0.171 & 0.171 & 59 & \multirow[t]{5}{*}{$91.97 \pm 0.04$} \\
\hline & 100 & 0.156 & 0.154 & 0.156 & 0.155 & 62 & \\
\hline & 150 & 0.141 & 0.145 & 0.144 & 0.143 & 65 & \\
\hline & 200 & 0.111 & 0.109 & 0.113 & 0.111 & 73 & \\
\hline & 250 & 0.101 & 0.106 & 0.108 & 0.105 & 75 & \\
\hline
\end{tabular}

CPFrE: Citrus paradisi fruit ethanol; CPLE: Citrus paradisi leave ethanol; IC50: Inhibitory concentration; SCV: Scanvenging.

Table 3. Anti-proliferative activity of Citrus paradisi plant extract against HepG-2 cell line.

\begin{tabular}{ccccccc}
\hline \multirow{2}{*}{ Code } & \multicolumn{5}{c}{ Concentrations (Mean \pm S.E) } \\
\cline { 2 - 6 } & $25 \mu \mathrm{g}$ & $50 \mu \mathrm{g}$ & $100 \mu \mathrm{g}$ & $300 \mu \mathrm{g}$ & $625 \mu \mathrm{g}$ & $1250 \mu \mathrm{g}$ \\
\hline UT & $100 \pm 0.00$ & $100 \pm 0.00$ & $100 \pm 0.00$ & $100 \pm 0.00$ & $100 \pm 0.00$ & $100 \pm 0.00$ \\
UT & $100 \pm 0.00$ & $100 \pm 0.00$ & $100 \pm 0.00$ & $100 \pm 0.00$ & $100 \pm 0.00$ & $100 \pm 0.00$ \\
UT & $100 \pm 0.00$ & $100 \pm 0.00$ & $100 \pm 0.00$ & $100 \pm 0.00$ & $100 \pm 0.00$ & $100 \pm 0.00$ \\
CPFrE (R1) & $44.4670 \pm 0.37$ & $51.8653 \pm 0.62$ & $69.7797 \pm 0.51$ & $81.017 \pm 0.01$ & $102.247 \pm 0.71$ & $179.087 \pm 7.8$ \\
CPFrE (R2) & $43.7523 \pm 0.31$ & $50.8817 \pm 0.63$ & $68.4743 \pm 0.52$ & $79.6967 \pm 0.02$ & $100.425 \pm 0.76$ & $176.897 \pm 7.71$ \\
CPFrE (R3) & $43.994 \pm 0.15$ & $51.39 \pm 0.64$ & $68.5597 \pm 0.51$ & $80.382 \pm 0.11$ & $100.899 \pm 0.7$ & $177.031 \pm 7.61$ \\
CPLE (R1) & $40.4633 \pm 0.11$ & $42.6597 \pm 1.47$ & $50.987 \pm 1.29$ & $73.167 \pm 3.52$ & $105.508 \pm 3.72$ & $105.596 \pm 0.65$ \\
CPLE (R2) & $39.8063 \pm 0.08$ & $41.826 \pm 1.46$ & $50.0063 \pm 1.26$ & $71.8187 \pm 3.53$ & $103.947 \pm 1.04$ & $103.658 \pm 3.65$ \\
CPLE (R3) & $40.3523 \pm 0.05$ & $41.7673 \pm 1.45$ & $50.434 \pm 1.12$ & $72.259 \pm 3.67$ & $104.201 \pm 0.96$ & $104.251 \pm 3.75$ \\
\hline
\end{tabular}

CPFrE: Citrus paradisi fruit ethanol; CPLE: Citrus paradisi leave ethanol; UT: Untreated; S.E: Standard error; R: Reading.
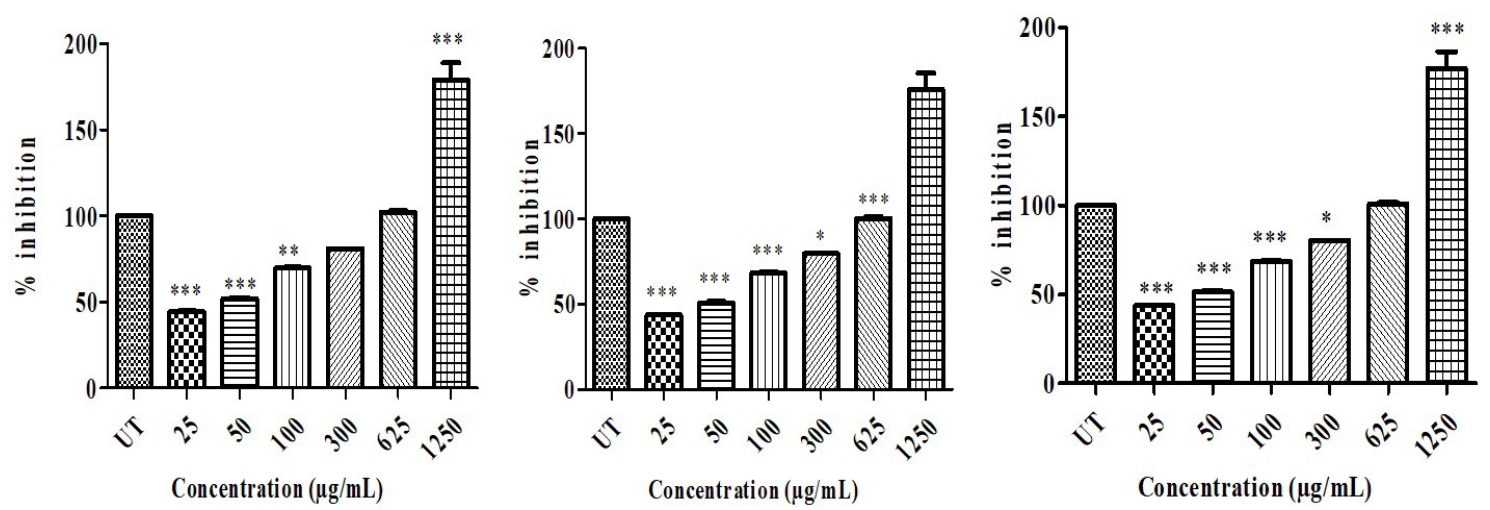

Figure 1. Anti-proliferative activity of ethanolic Citrus paradisi fruit extract. 


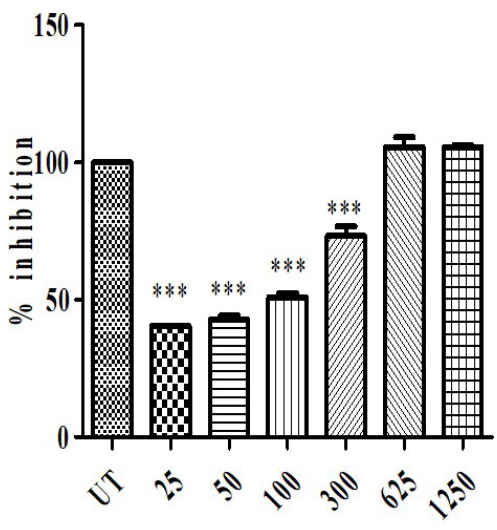

Concentration $(\mu \mathrm{g} / \mathrm{mL})$

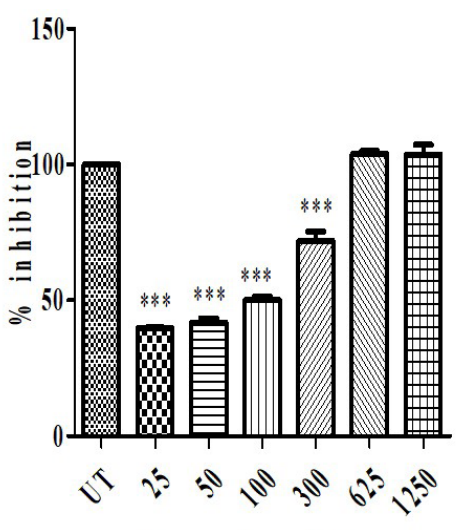

Concentration $(\mu \mathrm{g} / \mathrm{mL})$

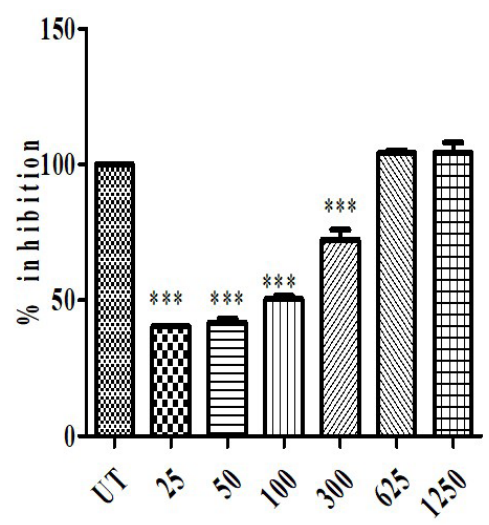

Concentration $(\mu \mathrm{g} / \mathrm{mL})$

Figure 2. Anti-proliferative activity of ethanolic Citrus paradisi leaves extract.

The concentration of ethanolic crude extract of fruits and leaves yields the value of IC50 (50\% growth inhibition) as 36.7073 and $71.5179 \mu \mathrm{g} / \mathrm{mL}$ respectively. The results demonstrated that fruits and leaves Citrus paradisi crude extracts had significant effect on HepG-2 cell line. IC50 values of Citrus paradisi plant extracts are given in Table 4.

It was reported that antiproliferative activity of grapefruit fruit extract on the growth of HepG-2 human liver cancer cells in vitro (Sun et al., 2013). The extract showed antiproliferative activity in a dose-dependent manner with the median effective dose (EC50) value of $130.09 \mathrm{mg} / \mathrm{mL}$. However, they did not identify the specific phytochemicals which were responsible for antiproliferative activity. Manassero et al. (2013) studied the antiproliferative activity of cold-pressed EO from mandarin peel and its principal component limonene. Mandarin EO and limonene exhibited IC50 of $0.063 \mu \mathrm{L} / \mathrm{ml}$ and $0.150 \mu \mathrm{L} / \mathrm{mL}$ against HepG-2 cells, respectively.

It was concluded that Citrus paradisi fruit extract exhibited good antioxidant and anti-proliferative activity. So, fruit extract is used for isolation and characterization of anti-proliferative compounds using TLC, column chromatography, FTIR techniques. TLC of ethanol extract of $C$. paradisi fruit ethanol ( $\mathrm{CPFrE}$ ) revealed the presence of 1 spot having $R_{f}$ values of 0.6 when a solvent phase of $100 \%$ ethanol was used, 2 spots/compounds having $R_{f}$ values of $0.58,0.61$ when a solvent phase of ethanol: chloroform (50:50) was used; 7 spots having $\mathrm{R}_{\mathrm{f}}$ values of $0.41,0.49,0.51,0.56,0.67,0.74,0.79$ when a solvent phase of ethanol: n-hexane (70:30) was used; 5 spots having $R_{f}$ values of $0.40,0.52,0.60,0.64,0.71$ when a solvent phase of methanol (100\%) was used. The $\mathrm{R}_{\mathrm{f}}$ value is given in Table 5 .

Gradient elution technique was followed for column chromatography. The column was first eluted with ethanol (100\%) and 2 fractions with 1 spot of $20 \mathrm{~mL}$ each were collected. The fractions collected were concentrated and TLC was performed to identify the presence of single compound. After that column was eluted with different combination of solvents such as ethanol: chloroform (50:50), ethanol: n-hexane (70:30) and methanol (100), 3 fractions with 2 spots, 3 fractions with 3 spots, 4 fractions
Table 4. IC50 of Citrus paradisi plant extracts by MTT Assay.

\begin{tabular}{ccc}
\hline \multirow{2}{*}{ IC50 } & \multicolumn{2}{c}{ Plant extracts } \\
\cline { 2 - 3 } & $\mathrm{CPFrE}(\mu \mathrm{g} / \mathrm{ml})$ & $\mathrm{CPLE}(\mu \mathrm{g} / \mathrm{ml})$ \\
\hline IC50 (R1) & 37.05 & 72.32 \\
IC50 (R2) & 36.38 & 70.92 \\
IC50 (R3) & $3 w 6.70$ & 71.32 \\
Mean \pm S.E & $36.71 \pm 0.194$ & $71.52 \pm 0.416$ \\
\hline
\end{tabular}

CPFrE: Citrus paradisi fruit ethanol; CPLE: Citrus paradisi leave ethanol; UT: Untreated; S.E: Standard error; R: Reading.

with 5 spots were collected respectively. Each fraction was concentrated and TLC was performed to visualize the spots under visible and UV light with two wavelengths such as long wavelength $365 \mathrm{~nm}$ and short wavelength $254 \mathrm{~nm}$. Each fraction was used to assess the anti-proliferative activity by MTT assay. Solvent of each fraction was used as negative control. The result is given in Table 6 .

IR spectra of CPFrE showed the strong and weak absorption peaks. The peaks at 3278.2, 2924.1, 1709.0, 1578.6, 1388.4, 1213.2, 1043.7 and $885.2 \mathrm{~cm}-1$ indicated the presence of carboxylic acid ( $\mathrm{O}-\mathrm{H}$ stretch), amine salt ( $\mathrm{N}-\mathrm{H}$ stretch), aromatic compounds $(\mathrm{C}=\mathrm{C}-\mathrm{C}$, aromatic ring stretch) cyclic alkene ( $\mathrm{C}=\mathrm{C}$ stretch), aldehyde ( $\mathrm{C}-\mathrm{H}$ bend $)$, fluoro compounds ( $\mathrm{C}-\mathrm{F}$ stretch) and alkene ( $\mathrm{C}=\mathrm{C}$ bend) respectively. The result is given in Table 7 and Figure 3.

Citrus maxima (Rutaceae), commonly known as Shaddock or pomelo is indigenous to tropical parts of Asia. The present study was aimed to screen the phytochemicals and FTIR analysis of Citrus maxima ethanolic leaf extract. The results revealed that the alkaloids, steroids, flavonoids, phenolic compounds, proteins, carbohydrates, cardiac glycosides and saponins were present in ethanolic extract. The FTIR spectroscopic studies revealed different characteristics peak value with various functional compounds in the extracts. The FTIR analysis of ethanol leaf extracts of Citrus maxima confirmed the presence of amide, alkenes, alkyne, alkane, ether, alcohol, ketone, alkyl halides and aromatics groups in the leaf extracts. The ethanolic extract of Citrus maxima 
Table 5. TLC profile of Citrus paradisi fruit ethanol (CPFrE) extract.

\begin{tabular}{|c|c|c|c|c|c|}
\hline Extract name & $\begin{array}{c}\text { Number of } \\
\text { spots detected }\end{array}$ & Solvent system & $\begin{array}{l}\text { Distance } \\
\text { travelled by } \\
\text { solvent }\end{array}$ & $\begin{array}{c}\text { Distance } \\
\text { travelled by } \\
\text { compounds }\end{array}$ & Rf value \\
\hline \multirow[t]{15}{*}{ CPFrE } & 1 & Ethanol (100\%) & 4.0 & 2.4 & 0.6 \\
\hline & 3 & Ethanol (50\%): Chloroform (50\%) & 3.8 & 2.2 & 0.58 \\
\hline & & & 3.8 & 2.3 & 0.61 \\
\hline & 7 & Ethanol (70\%): n- Hexane (30\%) & 3.9 & 1.6 & 0.41 \\
\hline & & & 3.9 & 1.9 & 0.49 \\
\hline & & & 3.9 & 2.0 & 0.51 \\
\hline & & & 3.9 & 2.2 & 0.56 \\
\hline & & & 3.9 & 2.6 & 0.67 \\
\hline & & & 3.9 & 2.9 & 0.74 \\
\hline & & & 3.9 & 3.1 & 0.79 \\
\hline & 5 & Methanol (100\%) & 4.2 & 1.7 & 0.40 \\
\hline & & & 4.2 & 2.2 & 0.52 \\
\hline & & & 4.2 & 2.5 & 0.60 \\
\hline & & & 4.2 & 2.7 & 0.64 \\
\hline & & & 4.2 & 3.0 & 0.71 \\
\hline
\end{tabular}

Table 6. Column chromatography for the isolation of bioactive molecules from Citrus paradisi fruit ethanol extract.

\begin{tabular}{lccccccc}
\hline $\begin{array}{l}\text { Solvent } \\
\text { system }\end{array}$ & Ratio & $\begin{array}{c}\text { Volume } \\
(\mathrm{ml})\end{array}$ & Fractions & $\begin{array}{c}\text { Number } \\
\text { of spots } \\
\text { detected }\end{array}$ & $\begin{array}{c}\text { Distance } \\
\text { travelled } \\
\text { by solvent }\end{array}$ & $\begin{array}{c}\text { Distance travelled by } \\
\text { compounds }\end{array}$ & $\begin{array}{c}\text { Retention factor (Rf) } \\
\text { value }\end{array}$ \\
\hline Ethanol & $100 \%$ & 40 & 1 & 1 & 4.0 & 2.5 & 0.63 \\
$\begin{array}{l}\text { Ethanol: } \\
\text { Chloroform }\end{array}$ & $50 \%: 50 \%$ & 30 & 2 & 2 & 3.8 & $2.1,2.4$ & $0.55,0.63$ \\
$\begin{array}{l}\text { Ethanol: } \\
\text { n. Hexane }\end{array}$ & $70 \%: 30 \%$ & 20 & 3 & 3 & 3.9 & $1.3,1.5,1.9,2.0,2.1,2.3$, & $0.33,0.38,0.49,0.51$, \\
Methanol & $100 \%$ & 30 & 4 & 5 & 4.0 & $1.9,2.4,2.7,2.9,3.2$ & $0.48,0.60,0.68,0.73$, \\
\end{tabular}

Table 7. FT-IR analysis of ethanolic Citrus paradisi fruits extract.

\begin{tabular}{|c|c|c|c|c|c|}
\hline Sr. No. & $\begin{array}{l}\text { Wavelength } \mathrm{cm}^{-1} 1 \\
\text { (Test samples) }\end{array}$ & Transmittance & $\begin{array}{l}\text { Wavelength } \mathrm{cm}^{-1} 1 \\
\text { (Reference article) }\end{array}$ & $\begin{array}{l}\text { Functional group } \\
\text { assignment }\end{array}$ & $\begin{array}{l}\text { Phyto-compounds } \\
\text { identified }\end{array}$ \\
\hline \multirow[t]{8}{*}{ CPFrE } & 3278.2 & 61.011 & $3300-2500$ & O-H stretching & Carboxylic acid \\
\hline & 2924.1 & 69.655 & $3000-2800$ & $\mathrm{~N}-\mathrm{H}$ stretching & Amine salt \\
\hline & 1709.0 & 54.361 & $2000-1650$ & $\mathrm{C}=\mathrm{C}-\mathrm{C}$ stretching & $\begin{array}{l}\text { Aromatic } \\
\text { compound }\end{array}$ \\
\hline & 1578.6 & 49.100 & $1650-1566$ & $\mathrm{C}=\mathrm{C}$ stretching & Cyclic alkene \\
\hline & 1388.4 & 50.485 & $1390-1380$ & C-H bending & Aldehyde \\
\hline & 1213.2 & 43.814 & $1400-1000$ & C-F stretching & Fluoro compound \\
\hline & 1043.7 & 35.153 & $1400-1000$ & C-F stretching & Fluoro compound \\
\hline & 885.2 & 54.066 & $895-885$ & $\mathrm{C}=\mathrm{C}$ bending & Alkene \\
\hline
\end{tabular}

has potential bioactive compounds and it could be utilized in pharmaceutical industries (Showmiya and Ananthi, 2018). Thin layer chromatography, Fourier transforms infrared spectroscopy and antiproliferative activity of Citrus paradisi fruit was not reported earlier.
Cancer has become one of the top killer diseases worldwide with the numbers of cases and deaths being expected to increase over the next 15 years. An increase in the incidences of drug resistant cancer and terrible side effects has resulted in a need for new anticancer compounds 


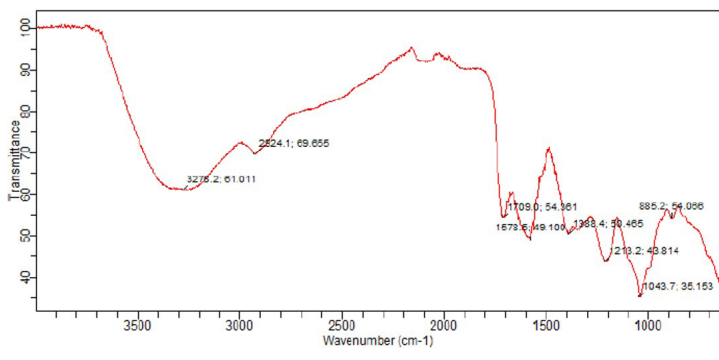

Figure 3. FTIR analysis of ethanolic Citrus paradisi fruits extract.

with diverse modes of action and little to no side effects. As whole extracts contain a variety of compounds, they will most likely have a variety of targets. Plants have been used for centuries to treat a variety of illnesses (AlGhannam et al., 2013; Ali et al., 2020; Mahmood et al., 2021; Afzal et al., 2021).

\section{Conclusion}

The present study demonstrated that ethanolic extracts of fruits of $C$. paradisi have good antioxidant and antiproliferative activity. The presence of functional groups in the fruit extract of Citrus paradisi was analyzed by FTIR. The present data suggests that the crude ethanolic extracts of the sample fruits are potential sources of phytochemicals that could be of great importance to the health and nutrition of humans and in the treatment of various diseases. The presence of various bio-active compounds confirms the application of fruit extract of Citrus paradisi for the treatment of breast cancer.

\section{Acknowledgements}

Authors are thankful to the director of The University of Lahore, Lahore, Pakistan.

\section{References}

ABU BAKAR, M.F., AHMAD, N.E., SULEIMAN, M., RAHMAT, A. and ISHA, A., 2015. Garcinia dulcis fruit extract induced cytotoxicity and apoptosis in HepG2 liver cancer cell line. BioMed Research International, vol. 2015, pp. 916902. http:// dx.doi.org/10.1155/2015/916902. PMid:26557713.

AFZAL, A., AFTAB, B., SIDDIQUE, J., BABAR, S., SOHAIL, A., YASIR, M. and HANIF, S., 2021. Phytochemical and antimicrobial activity analysis of Swertia chirayita and Artemisia absinthium plant extracts. Biological and Clinical Sciences Research Journal, vol. 2021, no. 1, pp. 1-6.

AL-GHANNAM, S.M., AHMED, H.H., ZEIN, N. and ZAHRAN, F., 2013. Antitumor activity of balanitoside extracted from Balanites aegyptiaca fruit. Journal of Applied Pharmaceutical Science, vol. 3, pp. 179-191.

ALI, Q., KHALIL, R., NADEEM, M., AZHAR, M., HAFEEZ, M. and MALIK, A., 2020. Antibacterial, antioxidant activities and association among plant growth related traits of Lepidium draba. Biological and Clinical Sciences Research Journal, vol. 2020, no. 1, pp. 1-6.
AMJED, S., JUNAID, K., JAFAR, J., AMJAD, T., MAQSOOD, W., MUKHTAR, N., TARIQ, K., SHARIF, M., AWAN, S.J. and ANSARI, F., 2017. Detection of antibacterial activities of miswak, kalonji and Aloe vera against oral pathogens and anti-proliferative activity against cancer cell line. BMC Complementary and Alternative Medicine, vol. 17, no. 1, pp. 265. http://dx.doi.org/10.1186/ s12906-017-1778-0. PMid:28506259.

ASHFAQ, F., ALI, Q., HAIDER, M., HAFEEZ, M. and MALIK, A., 2021. Therapeutic activities of garlic constituent phytochemicals. Biological and Clinical Sciences Research Journal, vol. 2021, no. 1, pp. 1-6.

ASHOKKUMAR, R. and RAMASWAMY, M., 2014. Phytochemical screening by FTIR spectroscopic analysis of leaf extracts of selected Indian Medicinal plants. International Journal of Current Microbiology and Applied Sciences, vol. 3, pp. 395-406.

BAILEY, D.G. and DRESSER, G.K., 2004. Interactions between grapefruit juice and cardiovascular drugs. American Journal of Cardiovascular Drugs, vol. 4, no. 5, pp. 281-297. http://dx.doi. org/10.2165/00129784-200404050-00002. PMid:15449971.

BIRADAR, S.R. and RACHETTI, B.D., 2013. Extraction of some secondary metabolites and thin layer chromatography from different parts of Centella asiatica L. (URB). American Journal of Life Sciences, vol. 1, no. 6, pp. 243-247. http://dx.doi.org/10.11648/j. ajls.20130106.11.

CARR, A.C. and MAGGINI, S., 2017. Vitamin C and immune function. Nutrients, vol. 9, no. 11, pp. 1211-1218. http://dx.doi.org/10.3390/ nu9111211. PMid:29099763.

CASTRO-VAZQUEZ, L., ALAÑÓN, M.E., RODRÍGUEZ-ROBLEDO, V., PÉREZ-COELLO, M.S., HERMOSÍN-GUTIERREZ, I., DÍAZ-MAROTO, M.C., JORDÁN, J., GALINDO, M.F. and ARROYO-JIMÉNEZ, M.M., 2016. Bioactive flavonoids, antioxidant behaviour and cytoprotective effects of dried grapefruit peels (Citrus paradisi Macf). Oxidative Medicine and Cellular Longevity, vol. 2016, pp. 8915729. PMid:26904169.

DANISH, P., ALI, Q., HAFEEZ, M., and MALIK, A., 2020. Antifungal and antibacterial activity of Aloe vera plant extract. Biological and Clinical Sciences Research Journal, vol. 2020, no. 1, pp. 1-6.

EL-SERAG, H.B., 2011. Hepatocellular carcinoma. The New England Journal of Medicine, vol. 365, no. 12, pp. 1118-1127. http://dx.doi. org/10.1056/NEJMra1001683. PMid:21992124.

FECHT JUNIOR, W.J. and BEFELER, A.S., 2004. Hepatocellular carcinoma: updates in primary prevention. Current Gastroenterology Reports, vol. 6, no. 1, pp. 37-43. http://dx.doi. org/10.1007/s11894-004-0024-3. PMid:14720452.

GUJJETI, R.P. and MAMIDALA, E., 2013. Phytochemical screening and thin layer chromatographic studies of Aerva lanata root extract. International Journal of Innovative Research in Science. Engineering Technology, vol. 1, pp. 5725-5730.

HARBORNE, J.B., 1973. Phytochemical methods. London: Chapman and Hall, pp. 149-188.

KELEBEK, H., 2010. Sugars, organic acids, phenolic compositions and antioxidant activity of grapefruit (Citrus paradisi) cultivars grown in Turkey. Industrial Crops and Products, vol. 32, no. 3, pp. 269-274. http://dx.doi.org/10.1016/j.indcrop.2010.04.023.

KHALIL, R., ALI, Q., HAFEEZ, M., and MALIK, A., 2020a. Phenolic acid profiling by RP-HPLC: evaluation of antibacterial and anticancer activities of Conocarpus erectus plant extracts. Biological and Clinical Sciences Research Journal, vol. 2020, no. 1, pp. 1-12.

KHALIL, R., ALI, Q., HAFEEZ, M., and MALIK, A., 2020b. Phytochemical activities of Conocarpus erectus: an overview. Biological and Clinical Sciences Research Journal, vol. 2020, no. 1, pp. 1-12.

MAHMOOD, H., ALI, Q., HAFEEZ, M., and MALIK, A., 2021. Antioxidant activity of Syzygium aromatium and Cinnamomum verum seed 
extracts. Biological and Clinical Sciences Research Journal, vol. 2021, no. 1, pp. 1-4.

MANASSERO, C.A., GIROTTI, J.R., MIJAILOVSKY, S., GARCÍA DE BRAVO, M. and POLO, M.M., 2013. In vitro comparative analysis of antiproliferative activity of essential oil from mandarin peel and its principal component limonene. Natural Product Research, vol. 27, no. 16, pp. 1475-1478. http://dx.doi.org/10.1 080/14786419.2012.718775. PMid:22943501.

MATHEW, S.J., SHAH, A., LAPIDUS, K., CLARK, C., JARUN, N., OSTERMEYER, B. and MURROUGH, J.W., 2012. Ketamine for treatment-resistant unipolar depression: current evidence. CNS Drugs, vol. 26, no. 3, pp. 189-204. http://dx.doi. org/10.2165/11599770-000000000-00000. PMid:22303887.

MORSY, N., 2014. Phytochemical analysis of biologically active constituents of medicinal plants. Main Group Chemistry, vol. 13, no. 1, pp. 7-21. http://dx.doi.org/10.3233/MGC-130117.

NITHIANANTHAM, K., SHYAMALA, M., CHEN, Y., LATHA, L.Y., JOTHY, S.L. and SASIDHARAN, S., 2011. Hepatoprotective potential of Clitoria ternatea leaf extract against paracetamol induced damage in mice. Molecules, vol. 16, no. 12, pp. 10134-10145. http://dx.doi.org/10.3390/molecules161210134. PMid:22146374.

OIKEH, E.I., OMOREGIE, E.S., OVIASOGIE, F.E. and ORIAKHI, K., 2015. Phytochemical, antimicrobial and antioxidant activities of different citrus juice concentrates. Food Science E Nutrition, vol. 4, no. 1, pp. 103-109. http://dx.doi.org/10.1002/fsn3.268. PMid:26788316.

OIKEH, E.I., ORIAKHI, K. and OMOREGIE, E.S., 2013. Proximate analysis and phytochemical screening of Citrus sinensis fruit wastes. The Bioscientist, vol. 1, pp. 164-170.

OKUNOWO, W.O., OYEDEJI, O., AFOLABI, L.O. and MATANMI, E., 2013. Essential oil of grapefruit (Citrus paradisi) peels and its antimicrobial activities. American Journal of Plant Sciences, vol. 4, no. 07, pp. 1-9. http://dx.doi.org/10.4236/ajps.2013.47A2001.

OU, M.C., LIU, Y.H., SUN, Y.W. and CHAN, C.F., 2015. The composition, antioxidant and antibacterial activities of cold pressed and distilled essential oils of Citrus paradisi and Citrus grandis (L.) osbeck. Evidence-Based Complementary and Alternative Medicine, vol. 2015, pp. 804091. PMid:26681970.

ROGHINI, R. and VIJAYALAKSHMI, K., 2018. Phytochemical screening, quantitative analysis of flavonoids and minerals in ethanolic extracts of Citrus paradisi. International Journal of Pharmacognosy and Phytochemical Research, vol. 10, pp. 11-16. http://dx.doi. org/10.13040/IJPSR.0975-8232.

SHOWMIYA, K. and ANANTHI, T., 2018. Phytochemical screening and FTIR analysis of Citrus maxima Linn. leaves. International Journal of Pharma Research and Health Sciences, vol. 6, pp. 2634-2637.

SIDDIQUE, A., IDREES, N., KASHIF, M., AHMAD, R., ALI, A., ALI, A., SIDDIQUA, A., and JAVIED, M., 2021. Antibacterial and antioxidant activity of Kiwi fruit. Biological and Clinical Sciences Research Journal, vol. 2020, no. 1, pp. 1-8.

SPANGENBERG, H.C., THIMME, R. and BLUM, H.E., 2009. Targeted therapy for hepatocellular carcinoma. Nature Reviews Gastroenterology \& Hepatology, vol. 6, no. 7, pp. 423-432. http://dx.doi.org/10.1038/nrgastro.2009.86. PMid:19488072.

SUN, Y.F., SONG, C.K., VIERNSTEIN, H., UNGER, F. and LIANG, Z.S., 2013. Apoptosis of human breast cancer cells induced by microencapsulated betulinic acid from sour jujube fruits through the mitochondria transduction pathway. Food Chemistry, vol. 138, no. 2-3, pp. 1998-2007. http://dx.doi.org/10.1016/j. foodchem.2012.10.079. PMid:23411336.

TRABER, M.G. and STEVENS, J.F., 2011. Vitamins C and E: beneficial effects from a mechanistic perspective. Free Radical Biology $\mathcal{E}$ Medicine, vol. 51, no. 5, pp. 1000-1013. http://dx.doi.org/10.1016/j. freeradbiomed.2011.05.017. PMid:21664268.

WAHYUNI, F.S., SHAARI, K., STANSLAS, J., LAJIS, N.H. and HAMIDI, D., 2016. Cytotoxic properties and complete nuclear magnetic resonance assignment of isolated xanthones from the root of Garcinia cowa Roxb. Pharmacognosy Magazine, vol. 12, suppl. 1, pp. S52-S56. PMid:27041859.

YANG, J.D. and ROBERTS, L.R., 2010. Hepatocellular carcinoma: a global view. Nature Reviews Gastroenterology \& Hepatology, vol. 7, no. 8, pp. 448-458. http://dx.doi.org/10.1038/nrgastro.2010.100. PMid:20628345. 